\title{
Eco-efficiency assessment in the agricultural sector: the Monte Novo irrigation perimeter, Portugal
}

\author{
Rodrigo Maia ${ }^{1}$, Cristina Silva*, Emanuel Costa ${ }^{1}$ \\ Faculty of Engineering of the University of Porto, Rua Dr. Roberto Frias, s.n., 4200-465, Porto, Portugal
}

\section{A R T I C L E I N F O}

\section{Article history:}

Received 31 March 2015

Received in revised form 1 April 2016

Accepted 5 April 2016

Available online 13 April 2016

\section{Keywords:}

Eco-efficiency assessment

Economic performance

Value chain optimization

\begin{abstract}
A B S T R A C T
In the context of an increasing commitment to water efficiency in the EU policy, a different approach for eco-efficiency assessment in the agricultural sector, at the meso level, was applied to the Monte Novo irrigation perimeter, located in the southern region of Portugal, targeting the new agricultural paradigm being implemented in the Alentejo region, focusing on the assessment of the environmental and economic impacts and the eco-efficiency performance associated with the water value chain for both the baseline scenario and a set of potential eco-efficiency agricultural improvements. These improvements would be resource efficient or pollution preventing. The agricultural eco-efficiency improvements which promote the efficiency of water use, like the Regulated Deficit Irrigation, allow the reduction of water and energy consumptions, whereas those promoting pollution prevention as the use of sludge from waste water treatment plants or the use of organic fertilizers, make it possible to reduce pollution caused by the use of chemical fertilizers. The selection of the agricultural eco-efficiency improvements to be tested was based on stakeholders' involvement and perceptions; the chosen methodology highlights the impacts of the application of each of those eco-efficiency improvements and the potential investments required, in order to facilitate stakeholders' decisions. The results to be presented focus on the relative performance of the scenarios corresponding to the application of each of the proposed eco-efficiency improvements compared to a baseline scenario. The set of eco-efficiency indicators evaluated is complemented with an economic performance assessment, allowing to present some policy recommendations on technology uptake.
\end{abstract}

๑) 2016 Elsevier Ltd. All rights reserved.

\section{Introduction}

Agriculture is considered a sector with a major contribution to environmental impacts, due to the important water resources demand volume but also due to the pollution emissions. The European Commission pointed out that the agriculture sector is the third most important sector to the GHG emissions, just behind the Energy and Transport sectors (European Commission, 2015). The increasing concern with environmental impacts and its relation with the economic value of different activities and organizations led to the increasing interest in the eco-efficiency assessment defined by the WBCSD in 1991 (Verfaillie and Bidwell, 2000). Since then, the eco-efficiency assessment became a relevant tool in the sustainability purpose of companies, individuals, governments and

\footnotetext{
* Corresponding author. Tel.: +351 225081916.

E-mail addresses: rmaia@fe.up.pt (R. Maia),cmsilva@fe.up.pt (C. Silva).

1 Tel.: +351 225081916 .
}

other organizations, settling its objectives as the reduction of resources consumption, the reduction of environmental impacts and emissions and the improvement of product and service value (Lehni, 2000). The eco-efficiency assessment assumes a growing importance in the decision making in several fields, allowing the evaluation and comparison of different production systems, manufacturing methodologies and materials. It has being used to evaluate several different problems like studying industrial waterservice systems as in Levidow et al. (2016) or comparing different biocomposites used in plastic pallet production like Korol et al. (2016).

Since 1998, the Organisation for Economic Co-operation and Development (OECD) promotes eco-efficiency initiatives in agriculture, pointing out the need to define strategies for improving eco-efficiency, as changes in farm practices concerning pest control and other activities that could reduce the environmental impacts of agriculture and at the same time cutting costs (OECD, 1998). More recently, the ISO 14045:2012 brought a new view on the eco- 
efficiency assessment methodology, defining the use of categorized indicators, related with the life cycle assessment framework.

The study presented here encompasses an eco-efficiency assessment focused on the meso-level scale, as developed in the frame of the FP7- ENV EcoWater project. The system's approach adopted, based on water service systems in different sectors, allowed to address the gap in meso-level eco-efficiency metrics. The analysis performed covers both the water supply and water use chains and considers the interrelations among different actors (EcoWater, 2013a).

Eco-efficiency assessment studies in the agriculture sector have already been developed, demonstrating the possible gains in the evaluation of the environmental impacts and of economic aspects, as shown in Gómez-Limón et al. (2012), which performed an ecoefficiency assessment of olive farms in Andalusia, considering some environmental and economic variables. This study pointed out the strong influence of the soil-climate conditions in ecoefficiency.

Some different studies, like Romero et al. (2004), focused on the irrigation perspective, analysing the possible improvements related to the application of measures and techniques, namely the regulated deficit irrigation and the subsurface drip irrigation. Also García et al. (2004) and Lopes et al. (2011) analysed the regulated deficit irrigation effects, although García et al. (2004) mainly focused on the economic side, performing a cost-benefit analysis.

Several other studies analysed the environmental impacts associated with the activities in the agriculture sector and, in some cases, compared the alternatives associated with the type of fertilization, testing the differences between the traditional and the organic perspectives. In Pelletier et al. (2008), the life cycle assessment results proved the capacity of organic agriculture to contribute to the reduction of energy consumption's global warming emissions and acidifying emissions in accordance to Canadian national emission values, mostly due to the differences between the production process of conventional nitrogen fertilizers (used in traditional agriculture) when compared with green manures production. Haas et al. (2001) also considered the life cycle assessment but, in this case, the comparison was made between three different farming approaches: intensive, extensified and organic. The best environmental results corresponded to the extensified farming and to the organic farming, with a special highlight to the latter alternative. In Wood et al. (2006), the analysis of off-farm activities impacts revealed significant importance. Although the results showed that indirect energy use, energy related emissions and GHG emissions are higher for the organic farming, the indirect contribution of those factors is significantly higher for the conventional farms, resulting in a higher influence in the overall impact results. Similarly, Pimentel et al. (2005) and Stolze et al. (2000) compared the traditional and organic farming, concluding the general capacity of reducing most of the environmental impact results by the application of organic approach and technologies.

\section{Study area}

Located in the southern region of Portugal, the Alqueva reservoir is the largest artificial lake in Europe with $250 \mathrm{~km}^{2}$ of surface area. The implementation of the Alqueva Multipurpose Project, which is an important source of water for several uses, has as its main purpose to supply water for agriculture, with a total benefited area of more than 115,000 ha. The project reflects a paradigm shift in the Alentejo region, fostering the transition from rainfed agricultural practices to irrigation and focusing on new economic activities, embracing new standards in innovation and technology. The Monte Novo irrigation perimeter, as one of Alqueva Project sub-systems, is part of that new agricultural paradigm, embracing more than 7800 ha. The perimeter began operating in 2009, with maize, olives and pastures as main crops, those representing approximately $80 \%$ of the Monte Novo perimeter irrigated area in 2012. The water volume necessary to supply the irrigation perimeter is directly abstracted from Alqueva's reservoir and transported by a network of channels and ducts, going through different reservoirs, to the irrigated area. This irrigation network can be subdivided in:

- the primary network, which corresponds to water abstraction from the Alqueva reservoir, water elevation and water transport to the secondary network;

- the secondary network, which enables the water distribution (under low or high pressure) to the different irrigated farms by means of several reservoirs for storage regulation.

The primary network is the responsibility of EDIA - "Empresa para o Desenvolvimento das Infraestruturas de Alqueva" (the entity responsible for Alqueva's project development and exploitation) that supplies water to the farmers' Association - AB Monte Novo "Associação de Beneficiários de Monte-Novo - responsible for the secondary network, that, on the other hand, supplies the water to the different farmers, through the secondary irrigation network. Nevertheless, currently, and during a transitional period, EDIA is still assuming the operational role allocated to the $\mathrm{AB}$ Monte Novo. At the farmers' level, the water supply is provided at low or high levels of pressure head, depending on the characteristics of the irrigation area considered. The Monte Novo irrigation perimeter is sub-divided in two different types of blocks:

- low pressure blocks (approximately 1 bar of pressure head at the hydrants), with lower water tariffs. The water supply for the low pressure sub-blocks is provided by gravity, requiring no water elevation in the secondary network.

- high pressure blocks (about 4 bar of pressure head at the hydrants), requiring lower investments from the farmers on own pumping stations but with higher water supply tariffs.

It should be noted that, in order to encourage the development of irrigated agriculture, the current water prices are subsidized. The low water tariffs, fixed by Law, are nonetheless increasing gradually until 2017, when water will be charged at the total price.

\section{Methodology for eco-efficiency assessment}

The eco-efficiency assessment is a quantitative process which enables the study of the environmental impacts of, in this case, the agricultural products along with their economic value. The relationship between environmental impact and economic value is expressed as a ratio, allowing an easy comparison between different options or strategies. The eco-efficiency assessment was performed taking into account the five phases of an eco-efficiency assessment (ISO, 2012): (i) Goal and Scope Definition, (ii) Environment Assessment, (iii) Value Assessment, (iv) Quantification of Eco-efficiency and, (v) Interpretation.

The environmental impacts were evaluated using the Life Cycle Assessment (LCA) tool. This is based on a life cycle approach and consists of a Life Cycle Inventory (LCI) analysis - inventory of relevant energy, resource inputs and environmental releases - to allow the Life Cycle Impact Assessment (LCIA): identification and evaluation of the potential environmental impacts associated with identified inputs (water, electricity, nitrogen fertilizer and phosphorus fertilizer, in the case of the Monte Novo case study) and releases/outputs (EcoWater, 2013a). 


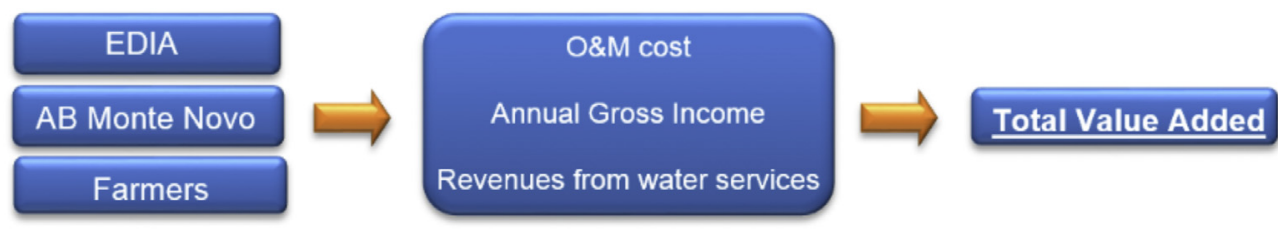

Fig. 1. Schema of the economic assessment for the Monte Novo case study.

The value assessment was performed considering the full life cycle of the product system. The values were calculated in monetary terms $(€)$ and expressed through costs, price, willingness to pay, added value, profit, etc. and aggregated into the Total Value Added (TVA) as the economic performance indicator (EcoWater, 2013a). Finally, the quantification of the eco-efficiency was determined by inter-relating the results of the environmental assessment with those of the value assessment: the eco-efficiency is estimated as the ratio between the value of the product/service and the environmental impacts identified.

More specifically for the Monte Novo case study, the ecoefficiency assessment was performed for the areas of land occupied by maize, olives and pastures, the three most relevant crops in the case study area. A baseline scenario was developed taking into account the current (2012) agricultural reality of the Monte Novo irrigation perimeter, by means of the data obtained primarily from local stakeholders and representative farmers. This last was extrapolated to all the area (and farmers) of the Monte Novo irrigation perimeter evaluated in this study (which corresponds to the maize, olives and pastures areas, representing almost $80 \%$ of the total irrigated area in 2012). The annual Operational and Maintenance $(O \& M)$ costs of the irrigation system, annual gross income of the farmers and the revenues from water services (for EDIA and AB Monte Novo) were evaluated in order to obtain the net cash flow. It should be noted that the (annual) amortization of the investment costs was included in the annual O\&M costs. The total value added for the irrigation perimeter area corresponds to the addition of the net cash flow of all the different actors considered. The methodology applied to the economic assessment is summarized in Fig. 1; the corresponding results/values obtained are presented in Table 4, an economic summary, which appears in the Section 3.1 on the discussion of the baseline scenario.

On the other hand, the environmental performance assessment allows to quantify the environmental impacts caused by agricultural activities. The approach adopted in this study considers the environmental impacts due to the input resources and materials and to the energy use. Regarding the system boundaries used for the LCA, a "cradle-to-gate" analysis was considered, that corresponding to an assessment of a (partial) product life cycle, starting from the extraction of primary resources (cradle) to the point the

Table 1

Characterization factors of foreground/background elementary flows (EcoWater, 2014).

\begin{tabular}{|c|c|c|c|c|c|c|c|c|}
\hline \multirow[b]{2}{*}{ Impact category } & \multirow[b]{2}{*}{ Unit } & \multicolumn{3}{|l|}{ Background } & \multicolumn{3}{|l|}{ Foreground } & \multirow{2}{*}{$\begin{array}{l}\text { Impact method } \\
\text { database }\end{array}$} \\
\hline & & $\begin{array}{l}\text { Electricity } \\
\text { production (per } \\
\text { kWh) }\end{array}$ & $\begin{array}{l}\text { N Fertilizer } \\
\text { production (per kg) }\end{array}$ & $\begin{array}{l}\text { P fertilizer } \\
\text { production (per kg) }\end{array}$ & $\begin{array}{l}\text { N Fertilizer to } \\
\text { water (per kg) }\end{array}$ & $\begin{array}{l}\text { P fertilizer to } \\
\text { water (per } \mathrm{kg} \text { ) }\end{array}$ & $\begin{array}{l}\text { Water } \\
\left(\text { per } \mathrm{m}^{3}\right)\end{array}$ & \\
\hline Climate change (CC) & $\mathrm{t} \mathrm{CO}_{2}$, eq & $8.0139 \times 10^{-4}$ & $1.93006 \times 10^{-3}$ & $0.39097 \times 10^{-4}$ & & & & CML-IA 2001 \\
\hline Eutrophication (E) & $\begin{array}{l}\mathrm{kg} \mathrm{PO}_{4}^{-3} \text {, } \\
\text { eq }\end{array}$ & 0.0003 & 0.00035 & 0.06724 & 0.42 & 3.06 & & CML-IA 2001 \\
\hline Acidification (A) & $\begin{array}{l}\mathrm{kg} \mathrm{SO} \\
\mathrm{eq}\end{array}$ & 0.00606 & 0.02339 & 0.02197 & & & & CML-IA 2001 \\
\hline Human toxicity (HT) & $\begin{array}{l}\mathrm{kg} 1,4- \\
\mathrm{DB}, \mathrm{eq}\end{array}$ & 0.06648 & 0.64951 & 0.16316 & & & & CML-IA 2001 \\
\hline $\begin{array}{l}\text { Respiratory inorganics } \\
\text { (RI) }\end{array}$ & $\begin{array}{l}\text { kgPM10, } \\
\text { eq }\end{array}$ & 0.00095 & 0.00314 & 0.00300 & & & & Traci 2 \\
\hline Aquatic ecotoxicity (AE) & kg DB & 0.00311 & 0.22896 & 0.08853 & & & & CML-IA 2001 \\
\hline $\begin{array}{l}\text { Terrestrial ecotoxicity } \\
\text { (TE) }\end{array}$ & $\mathrm{kg} \mathrm{DB}$ & 0.00154 & 0.00022 & 0.00063 & & & & CML-IA 2001 \\
\hline $\begin{array}{l}\text { Photochemical ozone } \\
\text { formation (POF) }\end{array}$ & $\begin{array}{l}\mathrm{Kg} \mathrm{C}_{2} \mathrm{H}_{4} \text {, } \\
\text { eq }\end{array}$ & 0.00025 & 0.00100 & 0.00093 & & & & CML-IA 2001 \\
\hline Minerals depletion (MD) & $\mathrm{kg} \mathrm{Fe}$, eq & 0.00018 & & & & & & ReCiPe \\
\hline $\begin{array}{l}\text { Fossil Fuels depletion } \\
\quad \text { (FFD) }\end{array}$ & MJ, eq & 8.4385 & 40.9486 & 6.2103 & & & & ReCiPe \\
\hline $\begin{array}{l}\text { Freshwater depletion } \\
\quad \text { (FD) }\end{array}$ & $\mathrm{m}^{3}$ & & & & & & 0.15 & ReCiPe \\
\hline
\end{tabular}

Table 2

Background processes and data sources (ELCD, 2014; USLCI, 2013).

\begin{tabular}{ll}
\hline Process & Data sources \\
\hline Electricity production & ELCD database (Process Name: Electricity Mix, AC, consumption mix, at consumer, 230 V PT) \\
Nitrogen fertilizer production & USLCI database (Process Name: Nitrogen fertilizer, production mix, at plant/kg/US \\
Phosphorus fertilizer production & USLCI database (Process Name: Phosphorus fertilizer, production mix, at plant/kg/US) \\
\hline Note: ELCD - European Life Cycle Database: USLCI - US. Life Cycle Inventory.
\end{tabular}


Table 3

Annual (2012) costs considered in the Monte Novo case study (baseline scenario).

\begin{tabular}{|c|c|c|c|c|c|c|c|c|}
\hline Cost $(€ /$ ha $)$ & Maize (LP) & Maize (HP) & Olives (I,LP) & Olives $(\mathrm{I}, \mathrm{HP})$ & Olives (SI,LP) & Olives (SI,HP) & Pastures (LP) & Pastures (HP) \\
\hline Fertilizers/pesticides & 522 & 522 & 69 & 69 & 150 & 150 & 63 & 87 \\
\hline Seeds & 220 & 220 & 0 & 0 & 0 & 0 & 0 & 0 \\
\hline Labour/equipment & 93 & 93 & 780 & 780 & 1169 & 1169 & 65 & 65 \\
\hline Other costs & 989 & 989 & 804 & 804 & 1005 & 1005 & 121 & 121 \\
\hline
\end{tabular}

*LP - Low Pressure (secondary network); HP - High Pressure (secondary network); I - Intensive production; SI - Super Intensive production.

Table 4

Economic summary, taking into account the different actors (baseline scenario; 2012).

\begin{tabular}{|c|c|c|c|c|}
\hline Actor & Annual O\&M cost $(€ / \mathrm{yr})$ & Annual gross income $(€ / \mathrm{yr})$ & Revenues from water services ( $€ /$ yr) & Net cash flow $(€ /$ yr $)$ \\
\hline EDIA & $684,709.65$ & 0.00 & $395,196.55$ & $-289,513.10$ \\
\hline AB Monte Novo & $265,224.07$ & 0.00 & $278,416.37$ & $13,192.29$ \\
\hline Farmers & $6,446,884.00$ & $9,395,490.00$ & $-673,612.92$ & $2,274,993.08$ \\
\hline Total & $7,396,817.73$ & $9,395,490.00$ & 0.00 & $1,998,672.27$ \\
\hline
\end{tabular}

products leave the agricultural system boundaries (before being provided to the consumer). In fact, no use or end life was taken into account. As presented in Fig. 2, two different levels/systems were considered: (i) the foreground system, focusing on all the stages along the water value chain used in the analysis, including the several resources (agro-chemicals and energy) used, and; (ii) the background system, including the raw materials and the energy production processes (e.g., in this case, the fertilizers and the electricity), supplied to the foreground system (EcoWater, 2013a).

More specifically, the environmental performance was evaluated according to eleven categories of environmental impacts presented in Table 1 and to their respective characterization factors. The background processes considered are presented in Table 2, with the indication of the database sources used.

The environmental impact for each material/resource used is calculated by multiplying the total amount of material/resource used in the irrigation perimeter by the respective characterization factor, for each of the 11 categories of environmental impact.

The development of the case study started with the assessment of the eco-efficiency of the baseline scenario, defined as representative of the current situation, then used for comparison with scenarios corresponding to the application of each potential ecoefficiency improvement in the case study area. These scenarios were grouped in two distinct categories for further comparison: improvements focusing on resource efficiency and improvements focusing on pollution prevention. An additional scenario focusing specifically on a change of the energy price was also evaluated. As for the baseline scenario, these basic proposed scenarios with potential application were evaluated regarding their specific environmental impacts, relevant costs, and the corresponding added value of implementation.

The eco-efficiency assessment for both the baseline scenario and eco-efficiency improvement scenarios was performed using specific tools ${ }^{2}$ that facilitate the evaluation of both the environmental impacts and the economic performance. These tools allowed to estimate the intermediate results concerning, resources, energy, water and costs, facilitating the evaluation of the scenarios. Finally, the analysis of the results together with the consideration of the economic and social context of the Monte Novo region led to the formulation of policy recommendations. These policy recommendations intend to promote eco-efficiency, having in mind the

\footnotetext{
2 SEAT - Systemic Environmental Analysis Tool, EVAT - Economic Value Chain Analysis and the EcoWater Toolbox, http://environ.chemeng.ntua.gr/ecoWater/ Default.aspx? $t=299$.
}

European guidelines for water management improvement (2000/ $60 / C E$ ) and the European Programme for Rural Development in Portugal (European Commission, 2013) but their viability is, obviously, strongly dependent on stakeholders' validation.

\subsection{Baseline scenario}

The baseline scenario assessment, which included an economic and environmental inventory, is the starting point for the study to be undertaken. As referred before, this scenario is used in order to evaluate, by comparison with it, the potential effect/impact of different eco-efficiency agricultural improvements that were identified as potentially applicable to the Monte Novo case study. It should be noted that the economic assessment presented here compiles different categories of agricultural production costs (water, energy, fertilizers, seeds, labour and equipment and other costs), per each of the referenced crops, for the year 2012, as presented in Table 3.

Table 4 presents the economic performance assessment for the baseline scenario, specifying the corresponding economic indicators obtained (in 2012) for each and all of the actors previously considered, following the methodology described in Section 2. The estimation of the Operational and Maintenance (O\&M) costs was based on the data provided in Table 3, the Annual Gross Income corresponds to the sale price of the agricultural goods produced by the farmers and the Revenues from Water Services were calculated in accordance to the water selling prices, fixed by law.

The Total Value Added obtained from the water use results from adding the net cash flow of the different actors considered. According to this estimation, the irrigated agricultural activity (corresponding to maize, olives and pastures) in the Monte Novo case study area generates (Table 4) a Total Value Added of about two Million euros.

In order to be able to perform an eco-efficiency analysis, a "functional unit" had to be defined: the functional unit is described as a service (or product) under study which is, for the Monte Novo case study, related to the freshwater consumption in Monte Novo irrigation perimeter (boundary). The functional unit allows to track all flows (inputs and outputs) associated to the consumption of freshwater, like electricity consumption, nitrogen and phosphorous fertilizers consumption and land occupation/utilization, all considered as inputs of the system.

The environmental inventory allowed to quantify the emissions caused by the use of water (foreground), electricity (background), nitrogen fertilizer (foreground and background) and phosphorous fertilizer (foreground and background) according to the 11 selected 


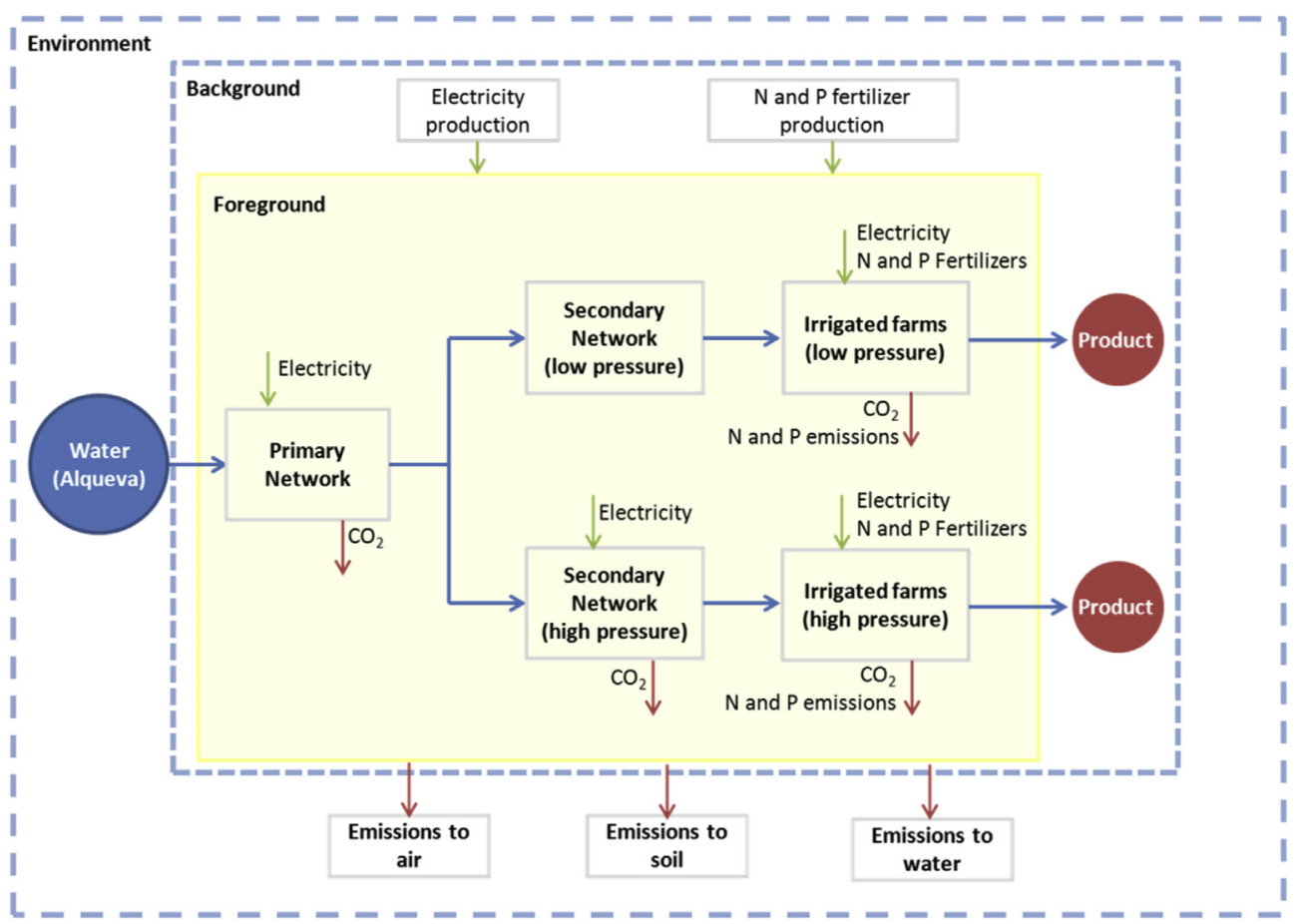

Fig. 2. Boundaries of the system with the foreground and background processes (EcoWater, 2014).

Table 5

Life Cycle Inventory - Input flows present in the irrigation perimeter of Monte Novo (baseline scenario).

\begin{tabular}{lr}
\hline Inputs/Resources & Total amount \\
\hline Freshwater (Alqueva) $\left(\mathrm{m}^{3}\right)$ & $21,264,275$ \\
Electricity (kWh) & $12,030,293$ \\
Nitrogen fertilizer $(\mathrm{kg})$ & 519,855 \\
Phosphorus fertilizer $(\mathrm{kg})$ & 300,125 \\
Land (ha) & 3673 \\
\hline
\end{tabular}

impact categories. Table 5 summarises the information on the LCI for the baseline scenario. This information allows the calculation of the environmental impacts associated with the Monte Novo irrigation perimeter. The output flows considered (Table 6) are the products of agricultural activity generated in the irrigation perimeter, the fertilizers accumulated in surface and groundwater and finally the waste water produced (stored both at the surface and underground).

Table 7 presents the environmental impacts from the background and foreground systems for the baseline scenario. The outputs "maize", "olives" and "pastures" have no environmental impact associated as they are the final product.

Table 6

Life Cycle Inventory - Output flows present in the irrigation perimeter of Monte Novo (baseline scenario)

\begin{tabular}{lr}
\hline Outputs & Total amount \\
\hline Maize (ton) & 20,055 \\
Olives (ton) & 18,360 \\
Pastures (ton) & 5090 \\
N to surface water $(\mathrm{kg})$ & 103,971 \\
$\mathrm{~N}$ to groundwater $(\mathrm{kg})$ & 103,971 \\
P to surface water $(\mathrm{kg})$ & 3001 \\
P to groundwater $(\mathrm{kg})$ & 3001 \\
WW to surface water $\left(\mathrm{m}^{3}\right)$ & $1,863,069$ \\
WW to groundwater $\left(\mathrm{m}^{3}\right)$ & $3,726,139$ \\
\hline
\end{tabular}

\subsection{Eco-efficiency improvements and basic scenarios}

After the assessment of the baseline scenario, and according to the know-how, interest and feedback from stakeholders of the region, namely farmers and institutions involved in water management of the area, a set of scenarios was defined considering the application of individual eco-efficiency improvements to the baseline scenario of the Monte Novo case study. Five different scenarios were defined and hereafter presented. Scenarios 1 to 4 are refined through the introduction of sub-scenarios that intend to cope with the specificities of each of the three studied crops (maize, olives and pastures). Each of these new scenarios corresponds to changes in the input and output flows in the life cycle inventory, requiring a new inventory analysis. At the economic level, costs as investment and management and operation costs were also considered, depending on the evaluated scenario.

\subsubsection{Scenario 1: regulated deficit irrigation}

Scenario 1 focuses on improving water saving by using Regulated Deficit Irrigation (RDI) for olives and maize which consists in the application of lower amounts of water comparatively to the currently defined water needs of the plant.

For maize, the RDI is applied during eight weeks following sowing, where only $70 \%-80 \%$ of the water required for the crop is provided. In the ninth and tenth weeks, as required by the phenological $^{3}$ stage of maize, water needs are fully satisfied (100\%). After this period, again, only $70 \%-80 \%$ of the water required by the crop is applied until the last phenological stage is reached (Toureiro et al., 2007).

For olives, a more specific monthly schedule is proposed, in accordance with the dependence of the irrigation needs on cultural

\footnotetext{
${ }^{3}$ The phenological stages refer to the different plant life cycle events associated to the seasonal and interannual variations in climate they are influenced by.
} 
Table 7

Environmental impacts from foreground and background systems (baseline scenario, 2012).

\begin{tabular}{|c|c|c|c|}
\hline Indicator (Unit) & Total & Foreground & Background \\
\hline Climate change ( $\mathrm{t} \mathrm{CO}_{2}$, eq) & 10,761 & 0 & 10,762 \\
\hline Fossil fuels depletion (MJ) & $124,668,758$ & 0 & $124,668,758$ \\
\hline Freshwater resource depletion $\left(\mathrm{m}^{3}\right)$ & $3,189,641$ & $3,189,641$ & 0 \\
\hline Eutrophication $\left(\mathrm{kg} \mathrm{PO}_{4}\right.$, eq) & 129,621 & 105,703 & 23,918 \\
\hline Human toxicity (kg1,4-DBeq) & $1,186,343$ & 0 & $1,186,343$ \\
\hline Acidification $(\mathrm{kg} \mathrm{SO}, \mathrm{eq})$ & 91,681 & 0 & 91,681 \\
\hline Aquatic ecotoxicity (kg1,4-DBeq) & 182,957 & 0 & 182,957 \\
\hline Terrestrial ecotoxicity (kg1,4-DBeq) & 18,786 & 0 & 18,786 \\
\hline Respiratory inorganics (kgPM10,eq) & 13,961 & 0 & 13,961 \\
\hline Photochemical ozone formation ( $\mathrm{kg} \mathrm{C}_{2} \mathrm{H}_{4}$, eq) & 3854 & 0 & 3854 \\
\hline Minerals depletion $\left(\mathrm{kg} \mathrm{Fe}^{-}\right.$, eq) & 2165 & 0 & 2165 \\
\hline
\end{tabular}

evapotranspiration (ETc). The monthly schedule was adapted from Fernández (2012).

Finally, in what concerns pastures, as, according to farmers' information and due to the edaphoclimatic conditions of the region, RDI is not aimed to be used for this crop in the Monte Novo area, it was not considered in the study.

\subsubsection{Scenario 2: substitution of fertilizer by sludge}

In this second scenario, a different approach was considered by means of the introduction of sludge from waste water treatment (WWT) plants in the area to allow the decrease of fertilizer's use in agriculture. The sludge is obtained by removing solids from the waste water and contains organic compounds and nutrients as nitrogen and phosphorus that can potentially be used for fertilization purposes. The sludge must be treated to remove heavy metals, pathogens or hazardous substances before being used for fertilization. The introduction of sludge from waste water treatment has two direct associated benefits: (i) to allow a decrease in the amount of fertilizers used in Monte Novo case study, and (ii) to prevent the deposition of sludge in landfill, causing a decrease in the environmental impacts and waste of resources.

More specifically, the application of sludge may be associated to the production of various crops, as for example, maize and pastures. In several studies, the application of sludge showed an increase in dry matter production on pastures (Serrão et al., 2009, 2010). In the study developed by Melo (2012), the use of sludge is shown to have increased the yield production of maize, with the increase depending directly on the amount of sludge used. The amount of sludge to be used for each crop was determined by taking into account the nutritional needs of nitrogen and phosphorus versus the levels of nitrogen and phosphorus existing in the sludge, taking into account the real availability of sludge in the Monte Novo area.

The application of sewage sludge in agriculture should take in account the presence of high levels of heavy metals. In Portugal, the application of sludge has to comply with the legislation (DL 276/ 2009) designed to regulate the use of sludge in agriculture.

\subsubsection{Scenario 3: decrease of chemical fertilizers' use}

This third scenario analyses the decrease in chemical fertilizers' use through the introduction of organic compounds appropriate for biological agriculture. Organic fertilizers consist of a mixture produced from natural organic waste trough natural processes such as composting or vermicomposting. This kind of fertilization allows re-allocating nutrients to crops, for example, from green waste, manure or municipal solid waste. The use of this type of fertilization can simultaneously provide nutrients and improve soil quality (structure, water retention capacity, microbiological activity) (Alcobia and Ribeiro, 2001).

However, one of the main disadvantages of the use of organic fertilizer is a consequent increase in costs. For maize, according to the information of a national supplier, it is advisable to use $700 \mathrm{~kg} /$ ha of organic fertilizer, which corresponds to an approximate cost of $420 € /$ ha. In the case of olives, the amount recommended is around $600 \mathrm{~kg} / \mathrm{ha}$, corresponding to a cost of $360 € / \mathrm{ha}$. For pastures, no values were provided. However, based on the content of phosphorus that may be present in the organic fertilizer and the phosphorus requirements of pastures, it was possible to estimate the amount of organic fertilizer to be used: $467 \mathrm{~kg} / \mathrm{ha}$, corresponding to a cost of $280 € /$ ha.

The main interest in the use of organic fertilizers combined with other environmentally favourable farming techniques is that it allows the production of, for example, organic olive oil and that, in this case (olives), the change from traditional agriculture to organic agriculture allows a $20 \%$ increase in the price to be paid to the farmer (Ferreira, 2010). For maize, the organic production selling price is between 300 and $330 € /$ ton against $260 € /$ ton on average for the conventional crop (EC, 2013). Finally, for pastures, due to the difficulty in achieving a consensual value of the increase in the price to be paid, only a $10 \%$ increase was considered in this study.

\subsubsection{Scenario 4: improvement of irrigation efficiency}

Another approach considered in this study was the improvement of the irrigation efficiency through the adoption of subsurface drip irrigation instead of drip irrigation for maize and olives. Subsurface drip irrigation (SDI) consists in the application of water below the soil surface though emitters (ASAE, 2005) with discharge rates similar to drip irrigation. This method of irrigation has been used all over the world in a wide variety of crops: woody crops and others such as maize, tomato, etc. As an example, studies conducted in Kansas (USA) enabled to conclude that it is possible to reduce in $25 \%$ the net irrigation needs with SDI, and maintain the same levels of productivity (Lamm and Trooien, 2003). In parallel, the reduction in water needs leads to an energy saving of the same magnitude.

The adoption of subsurface drip irrigation instead of drip irrigation increases the overall on-farm irrigation efficiency from $90 \%$ to $95 \%$. If a change from sprinkler to SDI is considered, the irrigation efficiency increases from $80 \%$ to $95 \%$. The investment costs associated with a subsurface drip irrigation system are considered to be around $5000 € / \mathrm{ha}$, and the corresponding operation and maintenance costs around $600 € /$ ha/year (12\% of the investment cost), for a 15 years' lifetime (EcoWater, 2013b).

\subsubsection{Scenario 5: new energy price}

The last presented scenario considers an improvement of irrigation costs through a new scheduling of irrigation, during periods of lower energy price, which could be achieved by different alternative contracts for purchase of electricity.

Generically, in Portugal, the energy user can choose between three different energy contracts with different energy prices according to specific time periods. For the contract "Tarifa Simples" 
("Simple tariff") the price of the KWh is the same throughout the day, $0.115 € / \mathrm{kWh}$. For the "Tarifa bi-horária" ("bi-hourly tariff") contract, the price of the KWh varies according to two preestablished time periods. Finally, the third type of contract, "Tarifa tri-horária" ("tri-hourly tariff") sets the price of energy according to three different time periods and to it corresponds the lowest price per kWh but only during a specific time period (10:00 PM to 08:00 AM).

Energy costs associated with agriculture in the Monte Novo irrigation perimeter, at the farmers' level, are mainly due to the use of water pumps to supply water to the crops in the low pressure blocks. After several contacts made with farmers' associations producing olives and/or maize, no disadvantages associated with the irrigation during the specific low cost energy period referred above were identified. Thus, in accordance, the scenario considered corresponds to choosing the "Tarifa tri-horária" contract, with a decrease in the energy price from $0.115 € / \mathrm{kWh}$ to $0.0831 € / \mathrm{kWh}$ (corresponding to a $28 \%$ reduction). Based on the gathered information, this scenario only takes into account olives and maize as no confirmation could be obtained for pastures regarding the applicability of this innovative option.

\section{Eco-efficiency assessment: main results}

According to the methodology presented in Section 3, the first step towards eco-efficiency assessment, in accordance to the EcoWater approach, was to assess the baseline scenario regarding the eco-efficiency indicators selected. In a second stage, the assessment of the scenarios envisaged to be used in the Monte Novo irrigation perimeter (scenarios 1 to 5 , Section 3) was carried out, comparing the values obtained for the different indicators with the baseline scenario's results: a higher value of an indicator obtained with the scenario implementation translates into an improvement in ecoefficiency.

\subsection{Baseline scenario}

The eco-efficiency assessment of the baseline scenario, was performed for the year 2012 as described in Section 3. The ecoefficiency indicators' values presented in Table 8 were obtained by dividing the Total Value Added, considered as the total net cashflow presented in Table 4, by the corresponding total environmental impact of each indicator, presented in Table 7.

\subsection{Basic scenarios}

The results of the different scenarios are grouped and compared according to their main focus: (i) promoting resource efficiency and, (ii) preventing pollution, allowing an easier evaluation and

Table 8

Eco-efficiency indicators (baseline scenario, 2012) (€/Unit).

\begin{tabular}{lr}
\hline Eco-efficiency indicator & Value \\
\hline Climate change $\left(€ / \mathrm{t} \mathrm{CO}_{2}\right.$, eq $)$ & 185.72 \\
Fossil fuels depletion $(€ / \mathrm{MJ})$ & 0.02 \\
Freshwater resource depletion $\left(€ / \mathrm{m}^{3}\right)$ & 0.63 \\
Eutrophication $\left(€ / \mathrm{kg} \mathrm{PO}_{4}^{-3}\right.$, eq) & 15.42 \\
Human toxicity $\left(€ / \mathrm{kg}^{3}, 4-\mathrm{Dbeq}\right)$ & 1.68 \\
Acidification $\left(€ / \mathrm{kg} \mathrm{SO}{ }_{2}^{-}\right.$, eq) & 21.80 \\
Aquatic ecotoxicity $(€ / \mathrm{kg} 1,4-\mathrm{Dbeq})$ & 10.92 \\
Terrestrial ecotoxicity $(€ / \mathrm{kg} 1,4-\mathrm{Dbeq})$ & 106.39 \\
Respiratory inorganics $(€ / \mathrm{kgPM} 10, \mathrm{eq})$ & 143.16 \\
Ozone formation $\left(€ / \mathrm{kg} \mathrm{C}_{2} \mathrm{H}_{4}\right.$, eq) & 518.58 \\
Minerals depletion $\left(€ / \mathrm{kg} \mathrm{Fe}^{-}\right.$, eq) & 922.98 \\
\hline
\end{tabular}

comparison of results. A new energy price scenario adds as a specific alternative scenario.

\subsubsection{Scenarios promoting resource efficiency}

Among the eco-efficiency improvements evaluated for the Monte Novo case study, the Regulated Deficit Irrigation (RDI) and the Subsurface Drip Irrigation (SDI) were the most relevant in promoting resource efficiency. The resource efficiency promotion, especially the water efficiency, is much relevant in this case study because of the significant rise of the water price up to 2017, as mentioned before (Levidow et al., 2014).

For the maize crop, two sub-scenarios were considered: a first sub-scenario considers the supply of only $70 \%$ of the crop water needs; in the second one, only $80 \%$ of the water needs of the culture are fulfilled. This translates into reductions of water consumption of 21\% (RDI Maize (21\%)) and 35\% (RDI Maize (35\%)).

For olives, two sub-scenarios were also considered based on the monthly schedule adapted from Fernández (2012) (referred in Section 3.2.1), leading to a reduction of water consumption of $64 \%$ for olives in intensive production (RDI Olives I) and $44 \%$ for olives in super intensive production (RDI Olives SI).

For pastures, RDI was not considered since its use is considered unusual for this crop.

Those percentages (for maize and olives) reflect the decrease in water requirements in each of the studied crops and the results obtained reflect the potential changes in the eco-efficiency relatively to the baseline scenario.

In the case of maize, the application of the RDI leads to a reduction in water consumption in the Monte Novo case study, between $11 \%$ and $17 \%$ (for the RDI Maize (21\%) and RDI Maize (35\%) scenarios respectively). For olives, the reduction verified is between 4\% (for RDI Olives SI scenario) and 7\% (for RDI Olives I scenario). Regarding energy savings, the application of the RDI for maize allows energy savings of $8 \%$ (RDI Maize (21\%)) and $12 \%$ (for RDI Maize (35\%)). For olives, the reduction achieved is $2 \%$ for the RDI Olives SI scenario and 5\% for the RDI Olives I scenario.

The SDI allows to decrease both water and energy consumptions. For maize, water and energy savings are around 18\% and 15\%, respectively. For olives, water savings are around 5\% while energy savings reach approximately $6 \%$. Although the SDI application allows an improvement of the environmental performance, the associated costs are higher when compared with the baseline scenario, leading to lower values of the eco-efficiency indicators. On the contrary, the increase in eco-efficiency is clear when using the Regulated Deficit Irrigation (Table A.1, in Appendix).

To subserve the inter-comparison, Fig. 3 presents the graphical representation of the eleven eco-efficiency indicators obtained with the application of the two referred irrigation improvements (RDI and SDI) and in the baseline scenario, for the two crops considered - a) maize (Fig. 3a) and b) olives (Fig. 3b). These graphs present dimensionless values resulting from dividing the ecoefficiency value obtained for each indicator by the eco-efficiency value of the baseline scenario. As the baseline scenario is used as a reference, a unit value corresponds to each of its indicators.

Fig. 3 confirms that whereas RDI leads to an improvement of eco-efficiency (higher values for all the indicators than in the baseline scenario, translated in Fig. 3 by spider graphs "outside" the one representing the baseline scenario), for both crops, the SDI leads to lower values of the selected eco-efficiency indicators.

The most relevant improvements obtained with RDI implementation are related with the "freshwater resource depletion" indicator as the water consumption decreases for each crop (foreground system). The most important improvement of this environmental impact, when compared with the baseline scenario, is obtained for maize (RDI Maize (35\%) sub-scenario) with a total 
a)

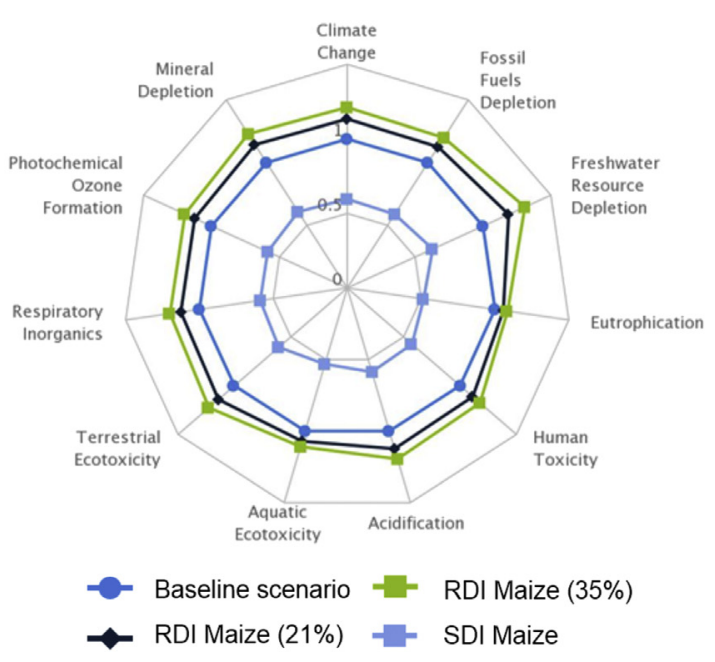

b)

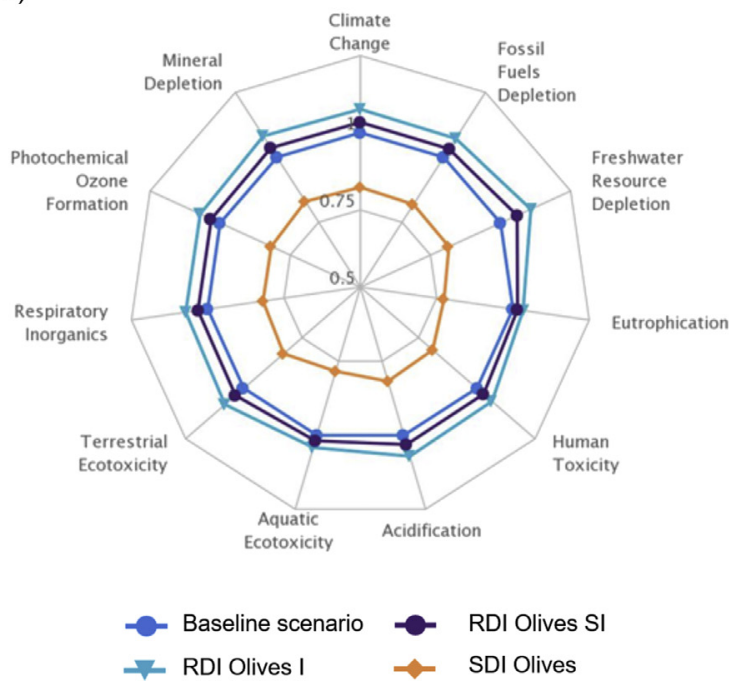

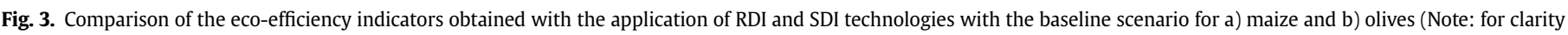
purposes, different dimensionless scales were considered in the spider graphs).

reduction of the water supplied to the system of about $17 \%$. This fact can be explained as maize requires an important amount of water per hectare. As a consequence, small changes on the water needs of this crop have great repercussions throughout the system.

Despite on a lower scale, the indicator "Minerals depletion" is also positively affected with the application of RDI, as this indicator is directly related with the electricity consumption. The smaller water consumption in the irrigation system for RDI directly originates a lower energy consumption and consequently a lower positive effect on minerals depletion.

As referred above, for SDI, the eco-efficiency decreases for all the environmental indicators, for both cultures. In fact, SDI reduces the environmental impacts but its implementation originates an important increase in costs which leads to a decrease of the ecoefficiency to values below those obtained for the baseline scenario.

\subsubsection{Scenarios focusing on pollution prevention}

In what concerns pollution prevention in the case study area, the two most suitable eco-efficiency improvements identified were (i) the use of sludge from waste water treatment plants and (ii) the use of organic fertilizers. The introduction of sludge/organic fertilizers in agriculture prevents pollution caused by the use of chemical fertilizers (nitrogen and phosphorus - foreground system).

Both sludge and organic fertilizers allow a high increase of the environmental performance of the environmental indicators mainly affected by the use of chemical fertilizers such as the "eutrophication" indicator (foreground system). Additionally, changes in the indicators associated with the life cycle of nitrogen and phosphorus production ("acidification", "human toxicity", "fresh aquatic ecotoxicity" and "fossil fuel depletion" indicators background system) are also verified.

Table A.1 (see Appendix) reports the different eco-efficiency indicators by crop obtained with the application of sludge and organic fertilizers that can potentially contribute in a positive way for pollution prevention. It should be noted that different subscenarios were considered, according to the crop considered:

- maize in high pressure blocks (HP) and maize in low pressure blocks (LP),
- olives in intensive (I) production in low pressure blocks (LP), olives in intensive production in high pressure blocks (HP) and olives in super intensive (SI) production in low pressure blocks (LP), and

- pastures in low pressure blocks (LP) and pastures in high pressure blocks (HP).

The consideration of sludge applied to maize leads to a reduction in chemical fertilizers of approximately $7 \%$ for nitrogen and $7 \%$ for phosphorus. For olives, the reduction verified is between $6 \%$ for nitrogen and 5\% for phosphorus. Finally, for pastures, the chemical fertilizer savings range from $5 \%$ to $6 \%$ for phosphorus.

For maize, the application of organic fertilizers results in a reduction of chemical fertilizers of about $67 \%$ for phosphorus and $77 \%$ for nitrogen. When applied to olives, organic fertilizers can reduce the consumption of chemical fertilizers in $23 \%$ for nitrogen and $21 \%$ for phosphorus. For pastures, there is a reduction of $12 \%$ for phosphorus.

Fig. 4 graphically summarizes the eco-efficiency comparison between the baseline scenario and the pollution prevention improvements proposed (use of sludge from waste water treatment plants and use of organic fertilizers) for the three crops considered: a) maize (Fig. 4a), b) olives (Fig. 4b) and c) pastures (Fig. 4c).

For maize and olives (Fig. 4a and b), a general improvement in eco-efficiency is obtained when using organic fertilizers in agriculture, with most significant results for maize. For this culture, the introduction of organic fertilizers increases more significantly the "Eutrophication" and "Aquatic Ecotoxicity" eco-efficiency indicators. The increase observed for the "Eutrophication" indicator is due to the substitution of chemical fertilizer by organic fertilizers (foreground system). For the "Aquatic Ecotoxicity" indicator, the positive effect in eco-efficiency is due to the decreased impact associated with the production of chemical fertilizers (background system). For olives, the eco-efficiency results follow a similar trend as maize.

On the opposite side, for pastures, in general terms, the ecoefficiency decreases (in comparison with the baseline scenario), when using organic fertilizers, due to the increase of costs that outweigh the positive effect of reducing the environmental impact.

When using sludge, eco-efficiency is increased for the three considered crops. However, for maize and olives, the benefits 
a)
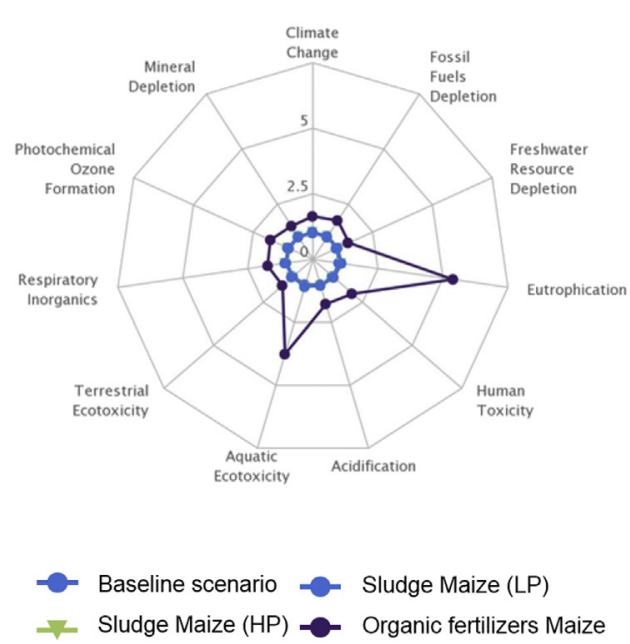

b)

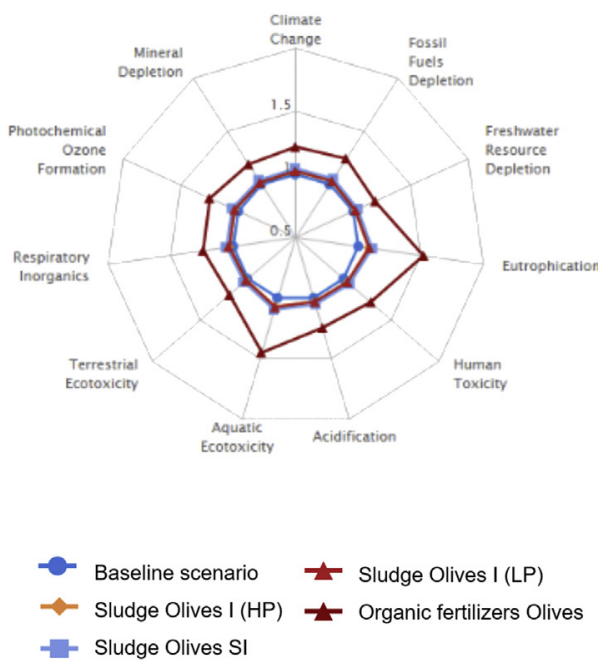

c)

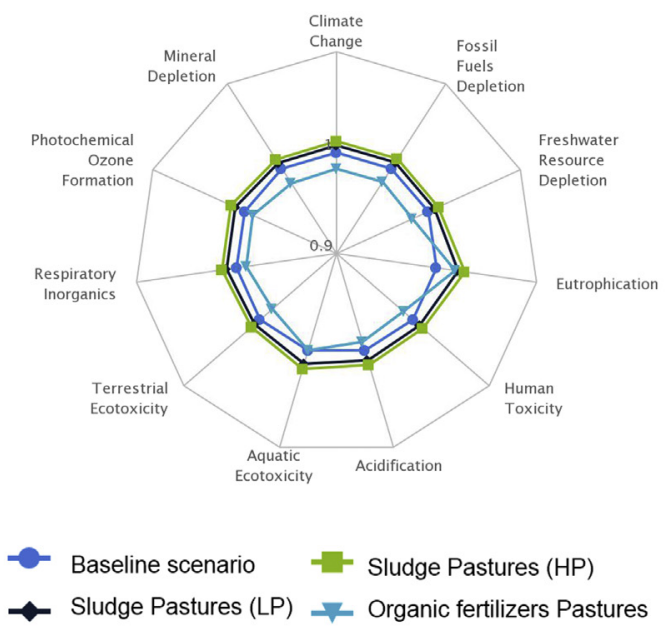

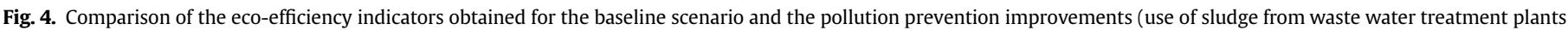

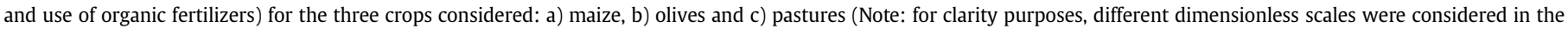
spider graphs).

obtained with its application are much more reduced than the ones verified with the introduction of organic fertilizers, and are not even visible in Fig. 4a (for Maize (LP) and Maize (HP)) and in Fig. 4b (for Olives I (HP)) since they almost coincide with the baseline scenario. This fact is explained by the insufficient quantity of available sludge from WWT plants in the of Monte Novo area, which does not allow meeting all the nutritional requirements of the irrigation perimeter for these crops using only sludge.

\subsubsection{New energy price scenario}

The scenario regarding the consideration of a new energy price is evaluated separately since it does not fit into the two above referred categories (promotion of resource efficiency and pollution prevention). The adaptation of the irrigation schedule to the low cost energy period allows a reduction in energy costs (annual O\&M costs) and consequently improves the economic performance whereas the environmental performance remains the same as for the baseline scenario. Thus, the increased eco-efficiency observed for both cultures (Table A.1, in Appendix) is only due to the increase in the economic performance.
For both selected cultures (maize and olives, as explained in Section 3.2.5), an improvement of the eco-efficiency is obtained when compared with the baseline scenario (Fig. 5). As expected, the decrease in energy costs has a positive effect on all the selected ecoefficiency indicators, for both cultures, with better global results for olives (Table A.1 and Fig. 5).

\section{Global comparison of the scenarios}

The results comparison presented above was performed within the considered categories - resource efficiency, pollution prevention and new energy price. However, the interpretation of the specific results, obtained for each of the indicators, may not highlight and make clear the best global eco-efficiency results comparing the different agricultural improvements. In that context, and to facilitate the presentation of the main findings of the study to stakeholders, a global comparison of the chosen potential agricultural improvements was carried out for each sub-scenario, following a three-step process: (i) normalization and aggregation of the environmental impacts into a single score (ReCiPe, 2012), (ii) 

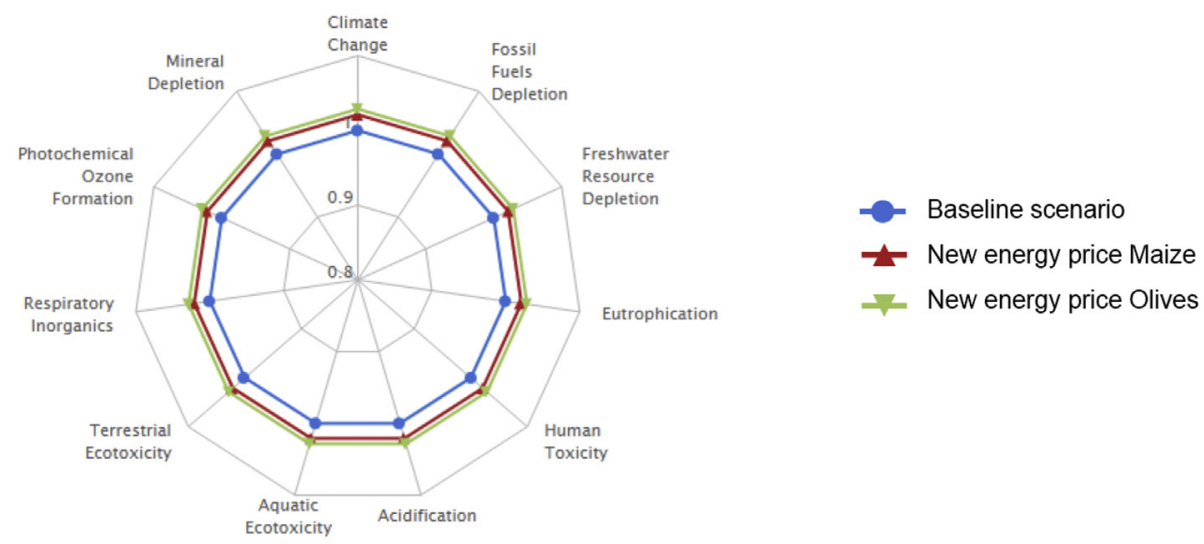

Fig. 5. Comparison of the eco-efficiency indicators in the baseline scenario and the new energy price scenario.

obtainment of dimensionless values for both TVA's and final scores (dividing by the sum of TVA's and final scores respectively), and (iii) ratio between dimensionless TVA and final score. Fig. 6 presents the obtained results that naturally translate similar eco-efficiency performance effects as described in Section 4. The use of organic fertilizers for maize presents the best results whereas, SDI in maize and olives and the use of organic fertilizers in pastures show worse results than the baseline scenario.

\section{Conclusions and policy recommendations}

The assessment of the eco-efficiency in the Monte Novo irrigation perimeter through the comparison between the baseline scenario and different eco-efficiency improvement scenarios allowed to identify the best scenarios for the maximization of economic productivity and the reduction of the environmental impacts. The several simulations carried out showed that the suggested agricultural eco-efficiency improvements to be implemented have particular influence on water, fertilizer and energy consumption. Water and energy savings are directly related to greenhouse emissions and to production costs. The type of fertilizers used influence the composition of the soil and the water quality in the surrounding areas of the irrigation perimeter as well as the market price of the agricultural products.

The approach followed in this study, based on the evaluation of basic scenarios grouped according to their main focus - promotion of resource efficiency or prevention of pollution -, was an important starting point for the future definition of more complex scenarios, combining different agricultural eco-efficiency improvements of the Monte Novo case study.

Based on the developed work, some general recommendations to increase the eco-efficiency in the Monte Novo irrigation

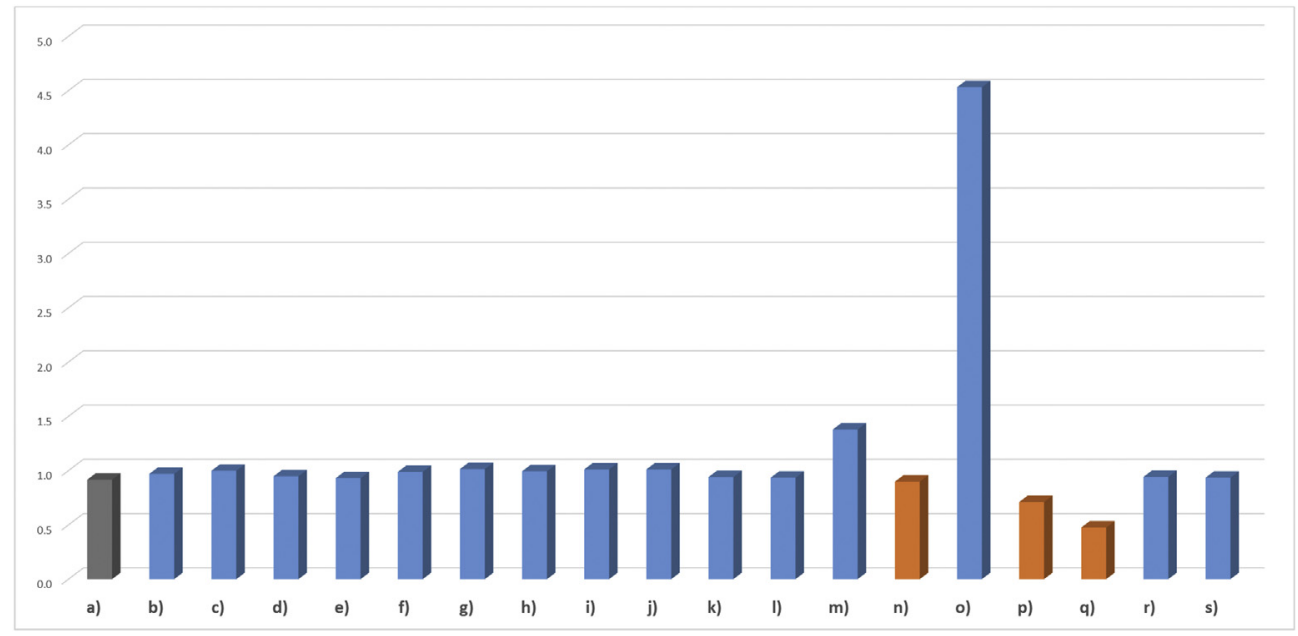

\begin{tabular}{|c|c|c|c|c|c|}
\hline a) & Baseline & h) & Sludge Olives I (LP) & o) & Organic fertilizers Maize \\
\hline b) & RDI Maize (21\%) & i) & Sludge Maize (HP) & p) & SDI Olives \\
\hline c) & RDI Maize (35\%) & j) & Sludge Maize (LP) & q) & SDI Maize \\
\hline d) & RDI Olives I & k) & Sludge Pastures (HP) & r) & New energy price Olives \\
\hline e) & RDI Olives SI & I) & Sludge Pastures (LP) & s) & New energy price Maize \\
\hline f) & Sludge Olives I (HP) & m) & Organic fertilizers Olive & & \\
\hline g) & Sludge Olives SI & n) & Organic fertilizers Past & & \\
\hline
\end{tabular}

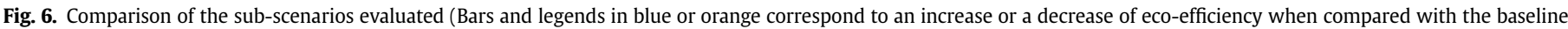
scenario). (For interpretation of the references to colour in this figure legend, the reader is referred to the web version of this article.) 
perimeter can already be proposed. In general terms, it came clear that the evaluation of the different scenarios should take into account political, economic, social and technological factors. Moreover, all stakeholders (farmers, water user organizations, policy and decision makers, etc.) perceptions and assessments should also be considered for the adoption of adequate eco-efficient measures and/or recommendations. Regarding specific actions, some needs could already be identified, namely:

- A feasibility study on the production of new crops economically more profitable, in the current economic context, in accordance with the new European agricultural policies, and increasing competitiveness, is required. The results obtained in this study showed that the reduction in water consumption increases the eco-efficiency of the Monte Novo irrigation perimeter. For this reason, the consideration of new crops with edaphoclimatic characteristics suitable for the region of Monte Novo is advisable. Products like cotton, linen or crops like beets, edible oil crops, fruits crops present themselves as an alternative to the current crop mix, as they have a high demand, high economic return associated with low water consumption (DGADR, 2005).

- The identification of possible barriers/weaknesses to the implementation of new eco-efficiency improvements moving beyond quantification, saving cost and resources. For example, RDI allows high water savings as demonstrated by the results achieved. Nevertheless, despite being a very viable solution, its implementation should be monitored, in order to avoid problems with the yield production in years with rare climatic conditions (EcoWater, 2013).
- The promotion of more eco-efficient agricultural practices providing adequate information to farmers, by means of training and workshops to increase the technical capacity. That shall take into account that most often the scientific knowledge is not duly transposed into reality. For example, RDI should be analysed and studied case by case as it may not be applicable in a generalized form for all regions (EcoWater, 2013). Fertilization with waste water sludge requires a prior analysis of the composition of the soil to be fertilized, namely as established for Portugal in the Decree-Law 446/91 (1991). This kind of information is extremely important to maximize crop yield taking into account environmental sustainability factors.

- The promotion of the link between the production sector (difficulty in selling the product) and the marketing sector (difficulty in obtaining the product), as required for the biological production of olive oil that presents a higher economic return to farmers but is not always easy to be sold in the current market.

\section{Acknowledgements}

'EcoWater: Meso-level eco-efficiency indicators to assess technologies \& their uptake in water use sectors', a collaborative research project of the 7th Framework Programme, grant agreement no. 282882, coordinated by the National Technical University of Athens (NTUA), http://environ.chemeng.ntua.gr/EcoWater/.

\section{Appendix A}

Table A.1Eco-efficiency indicators for the analysed scenarios ( $€ /$ Unit)

\begin{tabular}{|c|c|c|c|c|c|c|c|c|c|c|c|c|c|}
\hline \multicolumn{3}{|c|}{ Eco-efficiency Indicator } & \multirow{2}{*}{$\begin{array}{l}\mathrm{CC}(€ / \mathrm{t} \\
\left.\mathrm{CO}_{2}, \mathrm{eq}\right) \\
185.7\end{array}$} & \multirow{2}{*}{$\begin{array}{l}\text { FFD } \\
(€ / \mathrm{MJ}) \\
0.02\end{array}$} & \multirow{2}{*}{$\begin{array}{l}\text { FRD } \\
\frac{\left(€ / \mathrm{m}^{3}\right)}{0.63}\end{array}$} & \multirow{2}{*}{$\begin{array}{l}\mathrm{E}(€ / \mathrm{kg} \\
\frac{\left.\mathrm{PO}_{4}^{-3}, \mathrm{eq}\right)}{15.42}\end{array}$} & \multirow{2}{*}{$\begin{array}{l}\text { HT }(€ / \text { kg } 1,4- \\
\text { Db eq) } \\
1.68\end{array}$} & \multirow{2}{*}{$\begin{array}{l}\mathrm{A}(€ / \mathrm{kg} \\
\left.\mathrm{SO}_{2}^{-}, \mathrm{eq}\right) \\
21.80\end{array}$} & \multirow{2}{*}{$\begin{array}{l}\mathrm{AE}(€ / \mathrm{kg} \mathrm{1,4-} \\
\mathrm{Db} \text { eq) } \\
10.92\end{array}$} & \multirow{2}{*}{$\begin{array}{l}\mathrm{TE}(€ / \mathrm{kg} 1,4- \\
\mathrm{Db} \text { eq) } \\
106.4\end{array}$} & \multirow{2}{*}{$\begin{array}{l}\text { RI (€/kg } \\
\text { PM10, eq) } \\
143.2\end{array}$} & \multirow{2}{*}{$\begin{array}{l}\text { Of }(€ / \mathrm{kg} \\
\frac{\left.\mathrm{C}_{2} \mathrm{H}_{4}, \mathrm{eq}\right)}{518.6}\end{array}$} & \multirow{2}{*}{$\begin{array}{l}\mathrm{MD}(€ / \mathrm{kg} \\
\left.\mathrm{Fe}^{-}, \mathrm{eq}\right) \\
923.0\end{array}$} \\
\hline Baseline scena & ario & & & & & & & & & & & & \\
\hline \multirow[t]{6}{*}{$\begin{array}{l}\text { Resource } \\
\text { Efficiency }\end{array}$} & Maize & $\begin{array}{l}\text { RDI } \\
(21 \%)\end{array}$ & 210.5 & 0.02 & 0.75 & 16.29 & 1.87 & 24.50 & 11.70 & 121.5 & 161.2 & 582.8 & 1055.4 \\
\hline & & $\begin{array}{l}\text { RDI } \\
(35 \%)\end{array}$ & 225.0 & 0.02 & 0.82 & 16.74 & 1.98 & 26.06 & 12.12 & 130.4 & 171.7 & 619.74 & 1133.9 \\
\hline & & SDI & 110.8 & 0.01 & 0.39 & 7.98 & 0.97 & 12.78 & 5.81 & 64.49 & 84.27 & 303.9 & 561.1 \\
\hline & Olives & RDI I & 199.8 & 0.02 & 0.69 & 15.93 & 1.79 & 23.35 & 11.38 & 115.0 & 153.5 & 555.3 & 998.2 \\
\hline & & RDI SI & 192.0 & 0.02 & 0.66 & 15.65 & 1.73 & 22.49 & 11.13 & 110.1 & 147.7 & 534.9 & 956.1 \\
\hline & & SDI & 153.0 & 0.01 & 0.51 & 11.94 & 1.37 & 17.82 & 8.56 & 88.19 & 117.2 & 424.0 & 766.0 \\
\hline \multirow[t]{10}{*}{$\begin{array}{l}\text { Pollution } \\
\quad \text { Prevention }\end{array}$} & Maize & $\begin{array}{l}\text { Sludge } \\
\text { (HP) }\end{array}$ & 193.15 & 0.02 & 0.65 & 17.07 & 1.78 & 22.83 & 11.93 & 109.98 & 149.69 & 543.23 & 953.03 \\
\hline & & $\begin{array}{l}\text { Sludge } \\
\text { (LP) }\end{array}$ & 193.15 & 0.02 & 0.65 & 17.06 & 1.78 & 22.83 & 11.93 & 109.97 & 149.68 & 543.21 & 953.00 \\
\hline & & $\begin{array}{l}\text { Org. } \\
\text { Fert. }\end{array}$ & 304.4 & 0.03 & 0.95 & 83.00 & 3.38 & 38.72 & 41.11 & 162.5 & 249.3 & 923.4 & 1032.8 \\
\hline & Olives & $\begin{array}{l}\text { Sludge I } \\
\text { (HP) }\end{array}$ & 190.17 & 0.02 & 0.64 & 16.67 & 1.75 & 22.45 & 11.69 & 108.32 & 147.24 & 534.22 & 938.88 \\
\hline & & $\begin{array}{l}\text { Sludge } \\
\text { SI }\end{array}$ & 194.46 & 0.02 & 0.65 & 17.12 & 1.79 & 22.97 & 11.99 & 110.72 & 150.60 & 546.49 & 959.58 \\
\hline & & $\begin{array}{l}\text { Sludge I } \\
\text { (LP) }\end{array}$ & 190.5 & 0.02 & 0.64 & 16.77 & 1.75 & 22.50 & 11.75 & 108.46 & 147.54 & 535.36 & 940.04 \\
\hline & & $\begin{array}{l}\text { Org. } \\
\text { Fert. }\end{array}$ & 226.24 & 0.02 & 0.75 & 23.44 & 2.16 & 27.17 & 15.84 & 126.99 & 177.45 & 646.70 & 1097.79 \\
\hline & Pastures & $\begin{array}{l}\text { Sludge } \\
\text { (LP) }\end{array}$ & 187.06 & 0.02 & 0.63 & 15.75 & 1.70 & 22.02 & 11.08 & 107.15 & 144.57 & 523.90 & 929.12 \\
\hline & & $\begin{array}{l}\text { Sludge } \\
\text { (HP) }\end{array}$ & 187.83 & 0.02 & 0.63 & 15.86 & 1.71 & 22.13 & 11.13 & 107.59 & 145.23 & 526.33 & 932.89 \\
\hline & & $\begin{array}{l}\text { Org. } \\
\text { Fert. }\end{array}$ & 182.74 & 0.02 & 0.62 & 15.71 & 1.66 & 21.61 & 10.92 & 104.67 & 141.76 & 514.03 & 907.01 \\
\hline \multirow[t]{2}{*}{ Energy Price } & Maize (LI & P and HP) & 189.64 & 0.02 & 0.64 & 15.75 & 1.72 & 22.26 & 11.16 & 108.64 & 146.18 & 529.53 & 942.48 \\
\hline & Olives (LI & P and HP) & 191.05 & 0.02 & 0.64 & 15.86 & 1.73 & 22.43 & 11.24 & 109.44 & 147.27 & 533.47 & 949.48 \\
\hline
\end{tabular}

Note: Indicators are listed in Table 1. 


\section{References}

Alcobia, M.D., Ribeiro, J.R., 2001. Guide for Olive Orchards in Organic Farming, first ed. Edition Terra Sa, p. 111 (In Portuguese).

ASAE - American Society of Agricultural Engineering, 2005. ASAE Standards Engineering Practices Data, fortythird ed., p. 864 Michigan, ISBN 1892769476.

Decree-Law $n^{\circ} 446 / 91,1991$. Transposition of the Directive $n^{\circ} 86 / 278 / C E E$, from November 22nd.

DGADR - Direção Geral de Agricultura e Desenvolvimento Rural, 2005. Identificação das Potencialidades de Regadio de Alqueva (In Portuguese - Identification of irrigation potential in the Alqueva area).

EcoWater, 2013a. Eco-efficiency Assessment of Meso-level Water Use Systems - the EcoWater Approach (Internal Project Report).

EcoWater, 2013b. Innovative Technologies for Eco-efficiency Improvement in Agricultural Water Use (Internal Project Report).

EcoWater, 2014. Deliverable 2.4 Holistic Assessment of Eco-efficiency Improvements \& Scenario Analysis for the Agricultural Water Sector (Internal Project Report).

ELCD, 2014. European Platform on Life Cycle Assessment. http://eplca.jrc.ec.europa. eu/ELCD3/.

European Commission, 2013. http://www.slowfood.com/sloweurope/eng/news/ 175583/the-last-farmer-of-organic-corn.

European Commission, 2015. EU Agriculture and Climate Change.

Fernandéz, J.E., 2012. Interview in "Fruits, Vegetables and Flowers (in Portuguese).

Ferreira, D., 2010. Costs and Profitability in the Moura Region, Alentejo. Instituto Superior de Agronomia, Technical University of Lisbon (In Portuguese).

García, J., Romero, P., Botía, J., García, F., 2004. Cost-benefit analysis of almond orchard under regulated deficit irrigation (RDI) in SE Spain. Span. J. Agric. Res. 2 (2), 157-165.

Gómez-Limón, J.A., Picazo-Tadeo, A.J., Reig-Martínez, E., 2012. Eco-efficiency assessment of olive farms in Andalusia. Land Use Policy 29 (2), 395-406.

Haas, G., Wetterich, F., Köpke, U., 2001. Comparing intensive, extensified and organic grassland farming in southern Germany by process life cycle assessment. Agric. Ecosyst. Environ. 83 (1-2), 43-53.

ISO - International Organization for Standardization, 2012. ISO 14045, 2012. Environmental Management - Eco-efficiency Assessment of Product Systems Principles, Requirements and Guidelines, Switzerland.

Korol, J., Burchart-Korol, D., Pichlak, M., 2016. Expansion of environmental impact assessment for eco-efficiency evaluation of biocomposites for industrial application. J. Clean. Prod. 113, 144-152.

Lamm, F., Trooien, T., 2003. Subsurface drip irrigation for corn production: a review of 10 years of research in Kansas, Micro-Irrigation: advances in system design and management. Irrig. Sci. 22, 195-200.

Lehni, M., 2000. Eco-efficiency. "Creating More Value with Less Impact”. World Business Council for Sustainable Development, pp. 1-32. Available at: http:/ www.wbcsd.org.
Levidow, L., Zaccaria, D., Maia, R., Vivas, E., Todorovic, M., Scardigno, A., 2014 Improving water-efficient irrigation: prospects and difficulties of innovative practices. Agric. Water Manag. 146, 84-94.

Levidow, L., Lindgaard-Jorgensen, P., Nilsson, A., Skenhall, S.A., Assimacopoulos, D., 2016. Process eco-innovation: assessing meso-level eco-efficiency in industria water-service systems. J. Clean. Prod. 110, 54-65.

Lopes, C.M., Santos, T., Monteiro, A., Rodrigues, M.L., Costa, J.M., Chaves, M.M., 2011 Combining cover cropping with deficit irrigation in a Mediterranean low vigor vineyard. Sci. Hortic. 129 (4), 603-612.

Melo, A., 2012. Use of Sludge from the Municipal Wastewater Treatment Plant in the Maize Crop. Master Thesis. at the Azores University (In Portuguese). http:// hdl.handle.net/10400.3/1342.

OECD, 1998. Eco-efficiency, p. 88. Available at: http://www.oecd-ilibrary.org/ environment/eco-efficiency_9789264040304-en.

Pelletier, N., Arsenault, N., Tyedmers, P., 2008. Scenario modeling potential ecoefficiency gains from a transition to organic agriculture: life cycle perspectives on Canadian Canola, corn, soy, and wheat production. Environ. Manag. 42 (6), 989-1001.

Pimentel, D., Hepperly, P., Hanson, J., Douds, D., Seidel, R., 2005. Environmental, energetic, and economic comparisons of organic and conventional farming systems. BioScience 55 (7), 573.

ReCipe, 2012. ReCiPe Mid/Endpoint Method, Version 1.08 December 2012.

Romero, P., Botia, P., Garcia, F., 2004. Effects of regulated deficit irrigation under subsurface drip irrigation conditions on water relations of mature almond trees. Plant Soil 260 (2), 155-168.

Serrão, M.G., Domingues, H., Fernandes, M., Martins, J., Pires, F., Saraiva, I. Fareleira, P., Matos, N., Ferreira, E., Campos, A.M., 2009. Contribution to the improvement of degraded soils under pastures through sewage sludge application, without environmental risks. J. "Ciências Agrárias" 32 (1), 258-272.

Serrão, M.G. Domingues, H., Fernandes, M., Martins, J., Pires, F. Saraiva, I. Fareleira, P., Matos, N., Ferreira, E., Campos, A.M., 2010. Impact of the application of urban residual sludge and mineral fertilizers in soils with pastures in the Alentejo region. J. “Ciências Agrárias” 33 (1), 139-149 (In Portuguese).

Stolze, M., Piorr, A., Häring, A., Dabbert, S., 2000. The Environmental Impacts of Organic Farming in Europe: Economics and Policy, vol. 6.

Toureiro, C.M., Serralheiro, R.P., Oliveira, M.R., 2007. Maximização da Economia da Agua em Regadio: Rega Deficitária Controlada. II Congresso Nacional de Rega e Drenagem, Portugal (In Portuguese -Maximization of the water economy in irrigated agriculture: the regulated deficit irrigation).

USLCI, 2013. U.S. Life Cycle Inventory Database. National Renewable Energy Laboratory. https://www.lcacommons.gov/nrel/search.

Verfaillie, H.A., Bidwell, R., 2000. Eco-efficiency: a Guide to Reporting Company Performance. World Business Council for Sustainable Development.

Wood, R., Lenzena, M., Deya, C., Lundieb, S., 2006. A comparative study of some environmental impacts of conventional and organic farming in Australia. Agric. Syst. 89 (2-3), 324-348. 